\title{
Perception of Local Community on Corporate Social Responsibility of Brewery Firms in Ethiopia
}

\author{
Fentaye Kassa Hailu ${ }^{1}$, K. Rama Mohana Rao ${ }^{2}$ \\ ${ }^{1,2}$ Andhra University, Department of Commerce \& Management Studies, Visakhapatnam, India
}

\begin{abstract}
The main objective of this study is to examine the perception of local communities towards corporate social responsibility (CSR) initiatives of Brewery firms in Ethiopia. For the study purpose, a cross-sectional research design and survey method was employed. Convenience sampling technique was used to select participants and collected primary data from a total of 595 local communities of major five brewery firms. The study involved some quantitative analyses with the use of statistical tools (descriptive and inferential). The finding of this study revealed that awareness level of local community about the firms' CSR initiatives was somewhat good, however, still there were substantial portion of the host community had low level of awareness about CSR initiatives. The study also suggested that the local community with high level of awareness had higher positive perception toward CSR initiatives of firms. In this study CSR initiatives were categorized under the headings of sponsorship and donation; community development and helping the poor; employment opportunities; and environmental responsibility. The study concluded that the local community had positive perception to all categories of CSR initiatives of brewery firms as they rated above the average point (above 3.0). However, firms accorded a limited attention to community development and helping the poor. This study will contribute to the previous research on the practical aspects of CSR by highlighting the influence of demographic factors on perceptions of individuals, including gender, age, and level of education. Thus, this study concluded that gender and level of education influence the perception of local community toward the CSR initiatives of brewery firms but not age factor.
\end{abstract}

Keywords: Corporate social responsibility, local community, Perception, stakeholder

\section{Introduction}

Every business organization operates within a given society and the relationships that an enterprise has with the society in which it operates have been discussed by many scholars in the context of corporate social responsibility (CSR here after) and stakeholder theory for decades. For example, [1] argued that business and society are interwoven rather than being distinct entities. More specifically, [2] has argued, there is a natural fit between the idea of CSR and an organization ${ }^{\text {ee }}$ stakeholder.

Various definitions of CSR imply corporate engagement with society referring to one process by which an organization expresses and develops its ,,corporate culture ${ }^{e c}$ and ,social consciousnessese $^{\text {ec }}$ [3]. For example, CSR can be defined as activities, decisions, or policies that organizations engage in order to effect positive social changes and environment sustainability [4], as well as the firm "e s considerations of, and response to issues beyond the narrow economic, technical, and legal requirements of the firm to accomplish social and environmental benefits along with the traditional economic gains with which the firm seeks [5]. Similarly, CSR is a set of management practices that ensures the company maximizes the positive impact of its operations on society or "operating in a manner that meets and exceeds the legal, ethical, commercial and public expectations that society has of business"[6]. According to European Commission [7], CSR is defined as a concept whereby companies integrate social and environmental concerns in their business operations and in their interaction with their stakeholders on voluntary basis. According to [8], CSR is a form of corporate investment characterized by a dual orientation towards the improvement of social welfare and of stakeholder relations.

The idea that measure of the overall performance of a company should be based on its combined contribution to economic prosperity, environmental quality, and social wellbeing has come to be called "triple bottom line" [9]. Organizations, along these lines, are deemed to responsible for their activities formally to their owners as well as in less well-defined ways to this much wider group of stakeholders. This perspective has become integral to the management of social and community issues. Businesses need to act honestly and ethically with respect to their internal management and auditing, but CSR also requires them to focus on their wider responsibilities. The issue of corporate social responsibility is a complex one for any industry, not the least so for the beverage alcohol industry. Alcohol industry players (producers, distributors, etc.) believe that a systematic integration of CSR into their business practices can make a positive impact on their economic, social, and environmental performance [10]. The beverage alcohol industry recognizes that good corporate citizenship is more than ensuring that its products are used safely and responsibly. It also entails balancing the needs of its employees for a safe and rewarding job, improving the environment in which they work, and positively engaging the wider culture in which they operate, with the needs of shareholders for a fair return on investment.

The Brewery business is a multi- national business complex that includes the producers as well as a large network of suppliers, distributors, wholesalers, and related industries, such as hotels, restaurants, bars and advertisers. The Ethiopian beer production and market now more or less operated by the private sector has indicated enormous change for the last few years. This booming of the beer market and increasing in production could lead a hand to other sectors ${ }^{\text {ee }}$ development through backward and forward economic integration. Hence, this would have an impact on social and environmental aspect of the country. Consequently, brewery firms ought to give high consideration to the interest of various stakeholders who affected by their operations. It is 


\section{International Journal of Science and Research (IJSR) \\ ISSN (Online): 2319-7064 \\ Index Copernicus Value (2013): 6.14 | Impact Factor (2014): 5.611}

imperative to note that, Brewery firms should incorporate CSR into their core business strategy with the aim that they can advantage out of it.

\section{Research Objectives}

The study attempted to examine the perception of the local community about the CSR initiatives of Brewery firms in Ethiopia. Specifically, the study will pursue the following objectives:

1)To determine the awareness level of local communities on CSR initiatives of firms

2)To explore the perception of local communities towards CSR initiatives of firms

3)To determine difference on perception among employees on the basis of their demographic characteristics

4)To determine difference on perception among employees on the basis of their level of awareness

\section{Stakeholder theory and CSR}

A strong reason behind why firms are motivated to invest in CSR program comes from the domain of stakeholder theory [11], [12], [13], and [14]. In relation to this, CSR aims to define what responsibilities business ought to fulfill, the stakeholder concept addresses the issue of whom business is or should be accountable to, and both concepts are clearly interrelated [15]. Stakeholder theory asserts that corporations should be motivated not only to pursue profit maximization, but other multiple objectives [16], [17] by meeting the needs of the company's different stakeholders; thus, corporations should manage and coordinate the various competitive and cooperative demands of stakeholders [18], [2]. [1] Wood and Jones (1995) suggested three roles of stakeholders to justify the importance of stakeholders, evaluation on CSR: (1) stakeholders are the source of expectations of CSR, (2) stakeholders experience the effects of CSR, and (3) stakeholders will make evaluation on CSR. Therefore, many scholars have applied the stakeholder approach to running their empirical studies, such as [19], [16], [20], [21], [22].

In the CSR studies, Stakeholder theory seems easier to manure in collecting and analyzing CSR data as evidenced by the proliferation of empirical studies that have essentially integrated a stakeholder approach [21]. The language of stakeholder theory was also easier to grasp by managers/practitioners as most organizations understood and defined obligations and responsibilities vis-à-vis their traditional stakeholders [19]. From a stakeholder theory perspective, corporate social performance can thus be assessed in terms of a company meeting the demands of its multiple stakeholder groups, and companies must seek to satisfy their demands as an unavoidable cost of doing business [18].

In the literature of CSR, stakeholder theory provides a theoretical foundation for firms to see how their activities affect on and are affected by other groups [23]. In simple words, stakeholders are classified as groups of people with common characteristics, interests or shared goals that may differ from other groups. [12] argued that stakeholders are groups who can influence and being affected by firms, including shareholders, customers, employees, and suppliers. Aside from these stakeholders, [24] asserted that firms are also expected to manage their responsibility to silent stakeholders, such as local communities and the environment. According to [25], there are a wide range of CSR practices that corporations can engage in and consequently some CSR activities will affect different stakeholder groups to varying degrees. For instance, some CSR activities that directly influence on local community members include donating money and being involved in community affairs and activities [26].

\section{Research Methodology}

For the study purpose, a cross-sectional research design was adopted. The research employed the survey method in assessing the views of the local communities about Corporate Social Responsibility. Convenience sampling technique was used to collect primary data from a total of 750 local residents (working in public organizations) of major five brewery firms such as: BGI Ethiopia, Meta Abo, Bedele, Harar and Dashen brewery firms. Closed ended self administered questionnaire was designed and distributed, thus, the return rate was $79.3 \%$ (595). The questionnaire was structured in a rating order of $1=$ strongly disagree; 2=disagree; 3=neutral; 4= agree; and 5=strongly agree. In this research study quantitative research was carried out and involved some quantitative analyses with the use of statistical tools (descriptive and inferential). For the analysis of quantitative data, the researcher utilized SPSS version 20. The measuring instrument used in this study was a structured questionnaire taken from [27] with some modifications.

\section{Pilot study}

Pilot test was performed to determine the appropriateness and relevance of the questions in the instrument. Test of content validity was performed which was measuring to the extent of the instrument provides adequate coverage, representativeness the universe, specificity, and clarity of the topic under study. The instrument was provided to two academicians and two practitioners who assessed each item thoroughly and confirmed that the content validity was pretty good. Therefore, content validity of the questionnaire was established. This early draft was also circulated and piloted on 25 local community of Dashen Brewery in the context of Ethiopia brewery firms. Based on the feedback from, several modifications were made to the wording of some questions, and some less important questions were deleted to reduce the length of the questionnaire.

\section{Reliability and Validity test}

The reliability of the data in the present research was assessed by Cronbach's Alpha. According to [28], Cronbach Alpha coefficient scores were used above a 0.7 cut-off value. Once pilot test was done items in the questionnaire were tested against their construct validity by using principal Component factor analysis with varimax rotation to extract principal factors. The two steps involved in the factor analysis were factor extraction and factor rotation. Factors with an eigenvalue greater than 1 were selected. According to [29], all the items should have a factor loading in absolute 


\section{International Journal of Science and Research (IJSR) \\ ISSN (Online): 2319-7064 \\ Index Copernicus Value (2013): 6.14 | Impact Factor (2014): 5.611}

value greater than 0.5 , with a cumulative variance explained of more than $40 \%$. The Bartlet test of Sphericity and KaiserMeyer-Olkin (KMO) statistical test was conducted prior to factor extraction and rotation to examine the adequacy of the samples for factor analysis.

\section{Result and Discussion}

\subsection{Factor analysis}

The Cronbach $\alpha$ value of the scale used in the research is 0.833 , and this value is above $70 \%$. In this phase of the study the factor analysis was applied. The compatibility of the data with the factor analysis was studied with KMO sampling adequacy and Barlett's test of sphericity. The KMO value is $0.911>0.7$. This figure shows the sample data are suitable for undergoing of factor analysis. The results of Barlett test was significant at $\mathrm{p}=0.000$ also make sense (Chisquare $=4344.147$ and $\mathrm{p}<0.005$ ). This means that the variables are correlated highly enough to provide a reasonable basis for factor analysis.

Table 1: KMO and Bartlett's Test

\begin{tabular}{|c|c|c|}
\hline \multicolumn{2}{|c|}{$\begin{array}{c}\text { Kaiser-Meyer-Olkin Measure of Sampling } \\
\text { Adequacy. }\end{array}$} & .911 \\
\hline \multirow{2}{*}{$\begin{array}{c}\text { Bartlett's Test of } \\
\text { Sphericity }\end{array}$} & Approx. Chi-Square & 4344.147 \\
\cline { 2 - 3 } & df & 105 \\
\cline { 2 - 3 } & Sig. & .000 \\
\hline
\end{tabular}

Table 2: Rotated Component Matrix ${ }^{\mathrm{a}}$

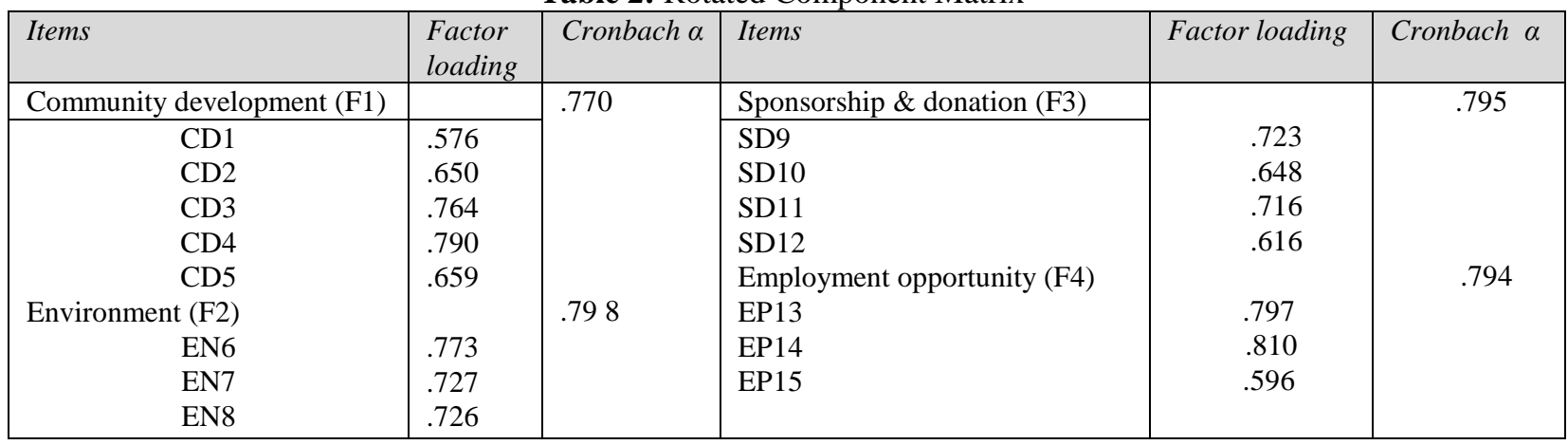

Extraction Method: Principal Component Analysis; Rotation Method: Varimax with Kaiser Normalization;

a. Rotation converged in 7 iterations

As shown in the Table 2, all the 15 items used for measuring CSR had a factor loading greater than 0.5. In the reliability test, internal consistency of each factor was evaluated using Cronbach"s alpha. The results of reliability test for all the factors have an alpha coefficient above 0.7 . The total variance explained of four factors was found to be 68.85\% (see Annexed Table A). The result of factor loadings of all items under Community development and helping the poor (F1); environment (F2); sponsoring and donation (F3); and employment opportunity (F4) were over 0.50 (see Table 2).

\subsection{Demographic profiles of Respondents}

Among respondents, there were 266 females and 329 males, which account for $44.7 \%$ and $55.3 \%$ respectively. About $80 \%$ percent of the respondents were between 18 and 36 years old, in which the age of $26-35$ is highest at $46.9 \%$. $19.5 \%$ of respondents were above 35 years old. There were $43.2 \%$ of respondents graduated from vocational training/college, $40.5 \%$ of respondents attended first degree and above and the remaining $16.3 \%$ of respondent completed secondary school (see Table 3).

Table 3: Demographic characteristics of the sample respondents

\begin{tabular}{|c|c|c|c|c|c|c|c|}
\hline Variables & & Frequency & $\%$ & Variables & & Frequency & $\%$ \\
\hline \multirow{3}{*}{ Gender: } & Male & 329 & 55.3 & \multirow{4}{*}{ Education: } & High school & 97 & 16.3 \\
\hline & Female & 266 & 44.7 & & TVET/Diploma & 257 & 43.2 \\
\hline & Total & 595 & 100 & & Degree\& above & 241 & 40.5 \\
\hline \multirow{4}{*}{ Age: } & $18-25$ & 200 & 33.6 & & Total & 595 & 100 \\
\hline & $26-35$ & 279 & 46.9 & & & & \\
\hline & 36\& above & 116 & 19.5 & & & & \\
\hline & Total & 595 & 100 & & & & \\
\hline \multicolumn{2}{|c|}{ Source: Sample survey } & & & & & & \\
\hline
\end{tabular}

\subsection{Awareness of CSR initiatives}

The research question about the level of awareness on CSR initiatives of brewery firms was posed to local communities. Among 595 respondents, slightly more than half percent (54.6\%) of respondents had moderate level of awareness; those who had high level of awareness were $27.6 \%$, and the remaining $17.8 \%$ of respondents had low level of awareness. Local communities rated a mean score of 2.10 a little higher than the average point. This figure indicated that employees ${ }^{\text {ee }}$ awareness about the CSR initiatives of the brewery firms was somewhat good. Thus, this level of awareness laid a ground for determining the perception of employees towards CSR initiatives of firms (see Table 4). 


\section{International Journal of Science and Research (IJSR) \\ ISSN (Online): 2319-7064 \\ Index Copernicus Value (2013): 6.14 | Impact Factor (2014): 5.611}

\subsection{Support community development and helping the}

\section{Poor}

The result of this study as shown in the Table 5, 55.1\% (329) respondents agreed or strongly agreed that brewery firms are supporting local sports, arts, education, health and cultural activities (mean=3.56 and $\mathrm{SD}=1.142$ ). About half percent (299) of respondents confirmed their agreement on the statement about investing on community development like roads, schools, hospitals and clean drinking water (mean=3.36 and SD=1.184). Almost one thirds (201) of respondents agreed or strongly agreed that firms used to help people below poverty line through financial support. Surprisingly, moderate mean score was recorded (3.04); this is because $36.5 \%$ (217) responses were undecided. Almost one thirds of (193) respondents agreed or strongly agreed that firms are helping the poor by holding free medical camps, financial aid to poor school children, poor ladies etc (mean=3.00 and SD=1.234). In this case, 36.8\% (219) responses were neutral. Slightly higher than forty percent (42.2\% and $n=251$ ) of the respondents agreed or strongly agreed on the contribution that has been made by firms to many projects to up lift the underprivileged. In general, respondents rated moderate to community development as part of CSR effort with mean score of 3.252 and standard deviation of 0.936 (see Table 5).

\subsection{Environmental responsibility}

The result of the study depicted that slightly more than half percent $(53.3 \%, n=321)$ of local communities conveyed their agreement on the proper and effective utilization of natural resources to produce cheaper and better goods with a moderate mean score of 3.47 and standard deviation of 1.246. 62\% (369) respondents agreed or strongly agreed on maintaining health environment, involves free from all sorts Survey result

\subsection{Provide employment opportunities}

Almost two thirds (393) of respondents conveyed their agreement on firms that creating a lot of jobs through growth and expansion (mean=3.75 and SD=1.165). Similarly, two thirds of respondents (403) agreed or strongly agreed on firms that providing a lot of jobs for local community (mean=3.80 and $\mathrm{SD}=1.120$ ). About half percent of respondents (299) indicated their agreement on the firms that recruiting lots of fresher thereby reducing unemployment. In general, respondents rated high to the employment opportunities created for the needy with mean score of 3.65 and standard deviation of 0.967 (see Table 8).

\subsection{Perception of CSR initiatives based on gender}

A result of t-test shows that gender difference influences the perception of CSR initiatives with statistical significance at the level of 0.05 (sig= 0.000). In this case female employees had higher level of perception than male counterpart. Several empirical evidences indicated that females are more ethical and more sensitive to and less tolerant of unethical subjects than males. However, the finding of this study inconsistent with the findings of to [30] and to [31] which of pollution and high mean score (3.65) was recorded with a standard deviation of 1.212. About half percent of the respondents indicated their agreement on the statement about the provision of regular voluntary information about environmental management to stakeholders. In this case almost high mean score (3.49) was registered with a standard deviation of 1.158. In general, respondents rated high on the environmental aspect of CSR initiatives (mean=3.54, $\mathrm{SD}=1.012$ ) (see Table 6).

\subsection{Sponsorship and donation}

The result of the study depicted that about three fourth (77.3\% , n=460) of respondents agreed or strongly agreed on companies involvement on the sponsorship of many local and national events with high mean score of 4.08 and standard deviation of 0.977 . About half percent (51.3\%) of respondents conveyed their agreement on the companies that encouraging employees to donate and actively engage in social causes (mean=3.563, SD=1.084). Almost 55\% (326) and $56.5 \%$ of respondent agreed or strongly agreed that brewery firms donate funds for social causes like poverty, HIV/AIDS etc. $($ mean=3.58, $\mathrm{SD}=1.144)$, and local and national NGO/charities (mean=3.59, D=1.062) respectively. In general, respondents rated high on firms ${ }^{\text {ee }}$ sponsorship to events, and donation to social causes and social organization (mean=3.74\&SD=0.804)(see:Table7).

Table 4: Awareness level of local community on CSR initiatives

\begin{tabular}{|l|c|c|c|c|}
\hline Awareness & Frequency & Percent & mean & St. deviation \\
\hline 1=low & 106 & 17.8 & & \\
2=moderate & 325 & 54.6 & \multirow{2}{*}{2.1} & 0.6671 \\
\hline 3=High & 164 & 27.6 & & \\
\hline \multicolumn{1}{|c|}{ Total } & 595 & 100 & & \\
\hline
\end{tabular}

found that gender as demographic factor do not influence the perception for the social and ethical behavior of firms. Therefore, gender influence on the perception of CSR has mixed results (see Table 9).

Table 5: Community development and helping the poor (F1) $(n=595)$

\begin{tabular}{|l|c|c|}
\hline \multicolumn{1}{|c|}{ Items } & Mean & St. deviation \\
\hline $\begin{array}{l}\text { Support local sport, arts, education, } \\
\text { health, cultural and other social activities }\end{array}$ & 3.563 & 1.142 \\
\hline $\begin{array}{l}\text { Invest in community development (roads, } \\
\text { schools, hospitals, clean drinking water) }\end{array}$ & 3.360 & 1.184 \\
\hline $\begin{array}{l}\text { Help people below poverty line to realize } \\
\text { their dreams by helping them financially }\end{array}$ & 3.040 & 1.184 \\
\hline $\begin{array}{l}\text { Help the poor in many ways by holding } \\
\text { free medical camps, giving financial aid to } \\
\text { poor school children, poor ladies etc }\end{array}$ & 3.000 & 1.234 \\
\hline $\begin{array}{l}\text { Contribute a lot of projects to up lift of } \\
\text { underprivileged }\end{array}$ & 3.290 & 1.132 \\
\hline \multicolumn{1}{|c|}{ Grand mean } & 3.252 & .936 \\
\hline Survey result & & \\
\hline
\end{tabular}




\section{International Journal of Science and Research (IJSR) \\ ISSN (Online): 2319-7064 \\ Index Copernicus Value (2013): 6.14 | Impact Factor (2014): 5.611}

Table 6: Perception on environmental issues (F2) $(\mathrm{n}=595)$

\begin{tabular}{|c|c|c|}
\hline Items & Mean & St. deviation \\
\hline $\begin{array}{c}\text { Utilize natural resources properly and } \\
\text { effectively to produce cheaper and better } \\
\text { goods }\end{array}$ & 3.47 & 1.246 \\
\hline $\begin{array}{c}\text { Maintain a healthy environment free from all } \\
\text { sorts of pollution in and around the business } \\
\text { area }\end{array}$ & 3.65 & 1.212 \\
\hline $\begin{array}{c}\text { Provide regular voluntary information about } \\
\text { environmental management to stakeholders }\end{array}$ & 3.49 & 1.158 \\
\hline Grand mean & 3.54 & 1.012 \\
\hline
\end{tabular}

Survey result

Table 7: Perception on sponsorship and donation (F3) $(n=595)$

\begin{tabular}{|c|c|c|}
\hline Items & Mean & St. deviation \\
\hline Sponsor on many local and national events & 4.0824 & .97698 \\
\hline $\begin{array}{c}\text { Encourage employees to donate and } \\
\text { actively engage in social causes }\end{array}$ & 3.5630 & 1.08431 \\
\hline $\begin{array}{c}\text { Donate fund for and actively engage in } \\
\text { social causes eg. Poverty, fighting against } \\
\text { HIV/AIDS etc }\end{array}$ & 3.5782 & 1.14380 \\
\hline $\begin{array}{c}\text { Donate money to local and national } \\
\text { NGO/charities }\end{array}$ & 3.5933 & 1.06171 \\
\hline Grand mean & 3.7357 & .80405 \\
\hline
\end{tabular}

Survey result

Table 8. Perception on employment opportunities (F4) $(n=595)$

\begin{tabular}{|c|c|c|}
\hline Items & Mean & St. deviation \\
\hline $\begin{array}{c}\text { Promote growth and expansion, which } \\
\text { means a lot of jobs for people }\end{array}$ & 3.746 & 1.165 \\
\hline $\begin{array}{c}\text { Give a lot of job opportunities to local } \\
\text { community }\end{array}$ & 3.802 & 1.120 \\
\hline $\begin{array}{c}\text { Recruit lots of fresher thereby reducing } \\
\text { unemployment }\end{array}$ & 3.395 & 1.172 \\
\hline Grand mean & 3.647 & .967 \\
\hline
\end{tabular}

Survey result

\subsection{Perception of CSR based on Age}

The ANOVA result shows that age of the respondents do not influence their perception toward CSR initiative of firms with statistical significance at 0.05 (sig=0.168). The finding of this study inconsistent with the findings of [31] which found that age as demographic factor significantly influences the employee,s perception for the social and ethical behavior of their firm. Therefore, age influence on the perception of CSR initiatives had mixed results (see Table 10).

\subsection{Perception of CSR based on the level of education}

The ANOVA result shows that the level of education influences the perception of respondents on CSR initiatives with statistical significance at the level of 0.05 ( $\mathrm{sig}=0.42$ ). The finding of this study is consistent with the findings of [31] which found that educational background as demographic factor significantly influences the perception for the social and ethical behavior of their firm (see Table 11).

\subsection{Perception of CSR based on awareness level}

The ANOVA result shows that awareness level of respondents influence their perception on CSR initiatives of firms with statistical significance at the level of 0.05 (sig=0.000). Those respondents who had high awareness perceived higher on CSR initiatives. The finding of this study consistent with the argument of [32], [33] asserted that respondents must be aware of the CSR imitative in order to have a positive impact on their perception (see Table 12).

Table 9: t-test for differences in perception of CSR initiatives based on gender

\begin{tabular}{|c|c|c|c|c|c|}
\hline Variables & Gender & Mean & $\begin{array}{c}\text { Std. } \\
\text { Deviation }\end{array}$ & $t$ & $\begin{array}{c}\text { Sig. (2- } \\
\text { tailed) }\end{array}$ \\
\hline \multirow{2}{*}{ CSR initiatives } & male & 3.4305 & .72629 & \multirow{2}{*}{} & \\
\cline { 2 - 6 } & female & 3.6827 & .78473 & -4.063 & .000 \\
\hline
\end{tabular}

$\mathrm{P}<0.05$ (2-tail)

Table 10: ANOVA test for the differences in perception of CSR based on Age

\begin{tabular}{|c|c|c|c|c|c|}
\hline Variable & Age & Mean & $\begin{array}{c}\text { Std. } \\
\text { Deviation }\end{array}$ & $F$ & Sig. \\
\hline \multirow{3}{*}{$\begin{array}{c}\text { CSR } \\
\text { initiatives }\end{array}$} & $18-25$ & 35999 & 068233 & \multirow{3}{*}{1.788} & \multirow{3}{*}{0.168} \\
\hline & $26-35$ & 3.4804 & 0.82052 & & \\
\hline & $>=36$ & 3597 & 074411 & & \\
\hline
\end{tabular}

$P<0.05$ (2- tail)

Table11: ANOVA test for the differences in perception of CSR based on education

\begin{tabular}{|c|c|c|c|c|c|}
\hline Variable & $\begin{array}{l}\text { Level of } \\
\text { education }\end{array}$ & Mean & $\begin{array}{c}\text { Std. } \\
\text { Deviation }\end{array}$ & $F$ & Sig. \\
\hline \multirow{3}{*}{$\begin{array}{c}\text { CSR } \\
\text { initiatives }\end{array}$} & High school & 3.5524 & 0.7076 & \multirow{3}{*}{3.184} & \multirow{3}{*}{0.042} \\
\hline & TVET/ Diploma & 3.6246 & 0.75879 & & \\
\hline & Degree \& above & 3.4528 & 0.78109 & & \\
\hline
\end{tabular}
$P<0.05$ (2- tail)

Table 12: ANOVA test for the differences in perception of CSR based on awareness level

\begin{tabular}{|c|c|c|c|c|c|}
\hline Variable & $\begin{array}{c}\text { Level of } \\
\text { awareness }\end{array}$ & Mean & $\begin{array}{c}\text { Std. } \\
\text { Deviation }\end{array}$ & F & Sig. \\
\hline \multirow{2}{*}{$\begin{array}{c}\text { Overall } \\
\text { CSR }\end{array}$} & low & 2.8997 & 0.6289 & & \\
\cline { 2 - 4 } & moderate & 3.6316 & 0.66686 & 57.174 & 0 \\
\cline { 2 - 4 } & High & 3.7841 & 0.79881 & & \\
\hline
\end{tabular}

$P<0.05$ (2- tail)

\section{Conclusion and Recommendations}

Awareness of social responsibility policies and perception may be as or more important than organizations ${ }^{\text {ee }}$ actual CSR policies themselves because it might have misperceptions of their firm"s policies or be unaware of its CSR activities. If the Local community are unaware of their firm 's CSR activities, the initiatives will have no impact on itse attitudes or behavior. Misperceptions of CSR activities could lead to unintended effect, such as frustration that the firm is using resources ineffectively. Accordingly, this study concludes that the awareness level of local community about the firms ${ }^{\text {ee }}$ CSR initiatives was somewhat good however, still there are substantial portion of the Local community had low level of awareness about CSR initiatives. The thesis also suggests that the local community with high level of awareness had higher positive perception toward CSR initiatives of firms.

\section{Volume 5 Issue 3, March 2016}




\section{International Journal of Science and Research (IJSR) \\ ISSN (Online): 2319-7064}

Index Copernicus Value (2013): 6.14 | Impact Factor (2014): 5.611

In this study CSR initiatives were categorized under the headings of sponsorship and donation; community development and helping the poor; employment opportunities; and environmental responsibility. The study concluded that the local community had positive perception to all categories of CSR initiatives of brewery firms as they rated above the average point (above 3.0). However, firms accorded a limited attention to community development and helping the poor.

This study contributes to previous research on the practical aspects of CSR by highlighting the influence of demographic factors on perceptions of individuals, including gender, age, and level of education. Thus, this study conclude that gender, level of education influence the perception of host community toward the CSR initiatives of brewery firms but not age factor.

In the light of the above the following suggestions may be useful for effective CSR programmes:

1)Companies should have CSR communication with all community and through various channels/media in order to develop perceptions, build good spirit and provide opportunity to express their opinion or determine the goal and encourage them to participate in CSR activities.

2)Local communities should be involved in CSR plan so that projects are designed according to the need of the community.

3)Local community should ensure they cooperate with the companies operating in their area to achieve the objectives of CSR to its fullest sense through amicable presentation of grievances.

\subsection{Limitation and Future direction}

This study is limited in its scope not only to the brewery firms but also limited to some part of CSR initiatives that directed to local community and environmental responsibility. Therefore, future study should include other alcoholic and non alcoholic beverage firms and also include other variable under CSR initiatives like customers, suppliers ${ }^{\text {ee }}$ related issues and etc. Moreover, the unit of analysis in this study was the local community; perception of other stakeholders towards CSR initiatives should be also examined.

\subsection{Contribution}

This study contributes to the existing body of knowledge in the field of CSR from the perspective of local community in general, adding value to Ethiopian literature in particular. Managers of the brewery and other industry can make use of this research output to devise their CSR strategies to address the social problems of the local community properly and effectively and so that they get benefit out of it.

\section{References}

[1] Wood, D. \& Jones, R. (1995). Stakeholder mismatching: A theoretical problem in empirical research on corporate social performance. International Journal of Organizational Analysis, 3, 229-267.

[2] Carroll, A.B. (1991). The pyramid of corporate social responsibility: toward the moral management of organizational stakeholders. Business Horizons, 34, 3948.

[3] Rupp, D. E., Gananpathy, J., Aguilera, R. V., \& Williams, C. A. (2006). Employeese reactions to corporate social responsibility: an organizational justice framework. Journal of Organizational Behaviour, 27, 537-543.

[4] guilera, R.V., Rupp, D.E., William, C.A and Ganapathi, J. (2007). Putting the $S$ back in corporate social responsibility: A multi-level theory of social change in organizations. Academy of management Review, 32(3), 836-863

[5] Davis, K., \& Blomstrom, R. (1971). Business, Society and Environment: Social power and Social response $\left(2^{\text {nd }}\right.$ ed). New York: McGraw-Hill

[6] Business for Social Responsibility (2001). Introduction to Corporate Social Responsibility. Retrieved from http://www.bsr.org/bsrresources/WhitePapers_IssueArea.cfm

[7] European Commission (2001).Promoting a European framework for corporate social Responsibility: Green Paper. Brussels, Commission of the European Communities, Doc/01/9

[8] Barnett, M. L. (2007). Stakeholder influence capacity and the variability of financial returns to corporate social responsibility. Academy of Management Review, 32(3), 794-816.

[9] Carroll, A.B. (1999). Corporate social responsibility: evolution of a definitional construct. Business and Society, 38, 268-95.

[10] Baggott, R. (2006). Alcohol strategy and the drinks industry a partnership for prevention. Leicester Business School, De Montfort University. Retrieved from http://www.jrf.org.uk/bookshop/eBooks/1955drugs-alcohol-prevention-uk.pdf

[11] Argandona, A. (1998). The stakeholder theory and the common good. Journal of Business Ethics, 17(9/10), 1093-1102.

[12]Freeman, R. E. (1984). Strategic Management: A Stakeholder Approach. Pitman, Boston.

[13] Harvey, B. and Schaefer,A.(2001).Managing relationships with Environmental stakeholders: A study of U.K. Water and Electricity Utilities. Journal of Business ethics, 30(3), 243-260.

[14] Post, F. R. (2003). A Response to the Social Responsibility of Corporate Management: A Classical Critique. Mid-American Journal of Business, 18(1), 2535.

[15] Kakabase, N., C. Rozuel and L.Lee-Davies (2005). Corporate social responsibility and stakeholder approach: A conceptual Review. International Journal of Business Governance and Ethics, 1(4), 277-302

[16] Pirsch, J., Gupta, S. and Grau, S.L. (2007). A Framework for Understanding Corporate Social Responsibility Programs as a Continuum: An Exploratory Study. Journal of Business Ethics, 70(2), 125-140. 


\section{International Journal of Science and Research (IJSR) \\ ISSN (Online): 2319-7064}

Index Copernicus Value (2013): 6.14 | Impact Factor (2014): 5.611

[17]Friedman, M. (1970, September 13). The social responsibility of business is to increase its profits. New York Times Magazine, pp. 32-33, 122, 124, 126.

[18] Ruf, B. M., Muralidhar, K., Brown, R.M., Janney,J.J. and K. Paul, K.( 2001). An empirical investigation of the relationship between change in corporate social performance and financial performance: a stakeholder theory perspective. Journal of Business Ethics, 32(2), 143-156.

[19]Clarkson, M.(1995). A Stakeholder Framework for Analyzing and Evaluating Corporate Social Performance. The Academy of Management Review, 20(1), 92-117.

[20]Lan, G., Growing, M., McManhon, S., Rieger, F. and King, N. (2008). A study of the relationship between personal values and reasoning of undergraduate business students. Journal of Business Ethics, 78(1), 121-139

[21] Jamali, D. (2008). A Stakeholder Approach to Corporate Social Responsibility: A Fresh Perspective into Theory and Practice. Journal of Business Ethics, 82, 213-231.

[22] Ferrary, M.(2009). A Stakeholder"s Perspective on Human Resource Management. Journal of Business Ethics, 87(1), 31-43.

[23] Ulmer, R. (2001). Effective crisis management through established stakeholder relationships: Malden Mills as a case study. Management Communication Quarterly, 14(4),590-614.

[24] Simmons, John (2004). Managing in the postmanagerialist era. Management Decision, 42(3/4), 601611.

[25] Spiller, R. (2000). Ethical Business and Investment: A Model for Business and Society. Journal of Business Ethics, 27(1), 149-160.
[26] McGehee, N., Wattanakamolchai, S., Perdue, Richard, R. \& Calvert, Esra Onat.(2009). Corporate Social Responsibility With in the U.S. Lodging Industry: an Exploratory Study. Journal of Hospitality \& Tourism Research, 33(3), 417-437.

[27]Gupta, S. (2011). Consumer stakeholder view of corporate social responsibility: a comparative analysis from USA and India. Social Responsibility Journal, 7(3), 363-38

[28] Nunnally, J.C., \&Bernstein, I.H.(1994).psychometric theory ( $3^{\text {rd }}$ ed.). New York:McGraw-Hill.

[29] Nunnally,J.C (1978).Psychometric Theory. New York: McGraw-Hill

[30] Stawiski, S., Deal, J., and Gentry, W. (2010). Employee perceptions of CSR: The implications for your organization. Center for Creative leadership. Retrieved from www.ccl.org

[31] Agrawal, C.P., Mathur A. and Saxena, A.A.(2015). Perception of Employees for Ethical and Social Responsibility of Firms Study at Rajsamand and Rajasthan. International Journal of Organizational Behaviour \& Management Perspectives, 4(1), 1387 1392

[32] Bhattacharya, C. B., \& Sen, S. (2004). Doing better and doing good. California Management Review, 47(1), 924.

[33] McWillams, A. \& Siegel, D. (2001). Corporate social responsibility: A theory of the firm perspective. Academy of Management Review, 26(1), 117-12

\begin{tabular}{|c|c|c|c|c|c|c|c|c|c|}
\hline \multirow[t]{2}{*}{ Component } & \multicolumn{3}{|c|}{ Initial Eigenvalues } & \multicolumn{3}{|c|}{ Extraction Sums of Squared Loadings } & \multicolumn{3}{|c|}{ Rotation Sums of Squared Loadings } \\
\hline & Total & $\%$ of Variance & Cumulative \% & Total & \% of Variance & Cumulative \% & Total & \%of Variance & Cumulative \% \\
\hline 1 & 6.737 & 44.913 & 44.913 & 6.737 & 44.913 & 44.913 & 2.879 & 19.196 & 19.196 \\
\hline 2 & 1.258 & 8.389 & 53.302 & 1.258 & 8.389 & 53.302 & 2.702 & 18.014 & 37.210 \\
\hline 3 & 1.157 & 7.715 & 61.017 & 1.157 & 7.715 & 61.017 & 2.384 & 15.896 & 53.106 \\
\hline 4 & 1.030 & 6.868 & 67.885 & 1.030 & 6.868 & 67.885 & 2.217 & 14.779 & 67.885 \\
\hline 5 & .700 & 4.664 & 72.549 & & & & & & \\
\hline 6 & .593 & 3.956 & 76.505 & & & & & & \\
\hline 7 & .566 & 3.775 & 80.279 & & & & & & \\
\hline 8 & .545 & 3.632 & 83.911 & & & & & & \\
\hline 9 & .480 & 3.201 & 87.112 & & & & & & \\
\hline 10 & .405 & 2.703 & 89.815 & & & & & & \\
\hline 11 & .397 & 2.649 & 92.464 & & & & & & \\
\hline 12 & .311 & 2.076 & 94.540 & & & & & & \\
\hline 13 & .299 & 1.995 & 96.535 & & & & & & \\
\hline \begin{tabular}{|l|}
14 \\
\end{tabular} & .293 & 1.951 & 98.486 & & & & & & \\
\hline 15 & .227 & 1.514 & 100.000 & & & & & & \\
\hline
\end{tabular}

Extraction Method: Principal Component Analysis. 